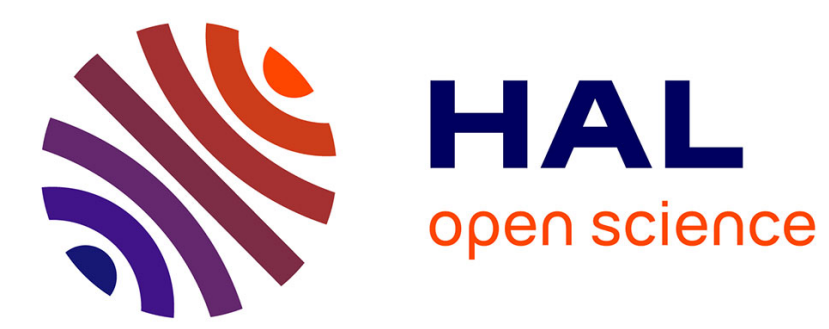

\title{
Yves Navarre. About a postmodern epistolary writing
} Lourdes Monterrubio Ibáñez

\section{To cite this version:}

Lourdes Monterrubio Ibáñez. Yves Navarre. About a postmodern epistolary writing. Romance Quarterly, 2021, pp.1-19. 10.1080/08831157.2020.1854555 . hal-03112052v2

\section{HAL Id: hal-03112052 \\ https://hal.science/hal-03112052v2}

Submitted on 21 Oct 2021

HAL is a multi-disciplinary open access archive for the deposit and dissemination of scientific research documents, whether they are published or not. The documents may come from teaching and research institutions in France or abroad, or from public or private research centers.
L'archive ouverte pluridisciplinaire HAL, est destinée au dépôt et à la diffusion de documents scientifiques de niveau recherche, publiés ou non, émanant des établissements d'enseignement et de recherche français ou étrangers, des laboratoires publics ou privés. 
This is an Original Manuscript on an article published by Taylor \& Francis in Romance Quarterly on the $15^{\text {th }}$ January 2021 , available at

https://www.tandfonline.com/doi/full/10.1080/08831157.2020.1854555

\author{
Yves Navarre. About a Postmodern Epistolary Writing \\ Lourdes Monterrubio Ibáñez \\ Complutense University of Madrid \\ loumonte@ucm.es \\ ORCID 0000-0003-0566-3666
}

\begin{abstract}
Yves Navarre's literary work is one of the greatest materialisations of epistolary writing in postmodern literature. This article aims to analyse the different elements and procedures through which the epistolary matter becomes a practice of postmodern writing that continues to evolve throughout his prolix literary oeuvre. First, the epistolary writing of fictional characters becomes an element of the renarrativisation that participates in processes of discontinuity: a progressive fragmental writing -from his first novel Lady Black (1971) to the last Dernier dimanche avant la fin du siècle (1994)-and the hybridisation with diaristic writing and literary metadiscourse -Le Petit Galopin de nos corps (1977), Kurwenal ou la Part des êtres (1977), Le Temps voulu (1979), Romances sans paroles (1982). Besides, these same practices are brought into the autofictional space, where the possibilities of hypertextuality are further deepened by quotation, intertext and metadiscourse-Biographie (1981), Romans, un roman (1988). Finally, the two spaces converge in an auto/alter-fiction in which postmodern diversel materialises through experimentation with alterity, giving rise to récits indécidables $-L$ 'Espérance de beaux voyages (1984), La terrasse des audiences au moment de l'adieu (1990). Throughout his entire literary work, and in all the aforementioned spaces, the abundant metadiscourse about epistolarity allows to draw a sort of postmodern phenomenology of epistolary activity.
\end{abstract}

Keywords: French Literature, Epistolary Writing, Postmodernity, Autofiction, Alterity

\title{
Introduction. Postmodern Literature
}

Yves Navarre's oeuvre, one of the greatest representations of French postmodern literature, includes a constant, crucial and innovative presence of the epistolary matter. The diversity of its forms -its insertion into literary work- and its uses -its instrumentalisation in narration- 
turn the author into the greatest exponent of epistolary writing in francophone postmodern literature:

La forme épistolaire présente plusieurs caractéristiques auxquelles l'auteur est sensible: elle exige une certaine concision; elle interpelle de façon directe, puisqu'elle s'adresse à un destinataire précis et invite généralement à une réponse; elle fixe l'instant; enfin, elle se prête aisément au mode de la confidence, à l'aveu, à l'expression de soi (Lannegrand 2000: $334)$.

This article aims to analyse the different elements and procedures through which epistolary material becomes a postmodern literary practice throughout his entire work. To this purpose, I present a brief description of the defining elements of literary postmodernism in order to study and analyse their presence in the epistolary practices of his novels.

Literary postmodernism is gestated, according to different authors, as the reaction to the limit-experience materialised by the Nouveau Roman from the end of the fifties until the end of the seventies. According to Marc Gontard, the scriptural practices that shape this response are defined by the presence of three narrative effects "discontinuité, hypertextualité, renarrativisation" (2013: 12). Postmodern renarrativisation is characterised by a successivity that does not necessarily imply a return to the supremacy of intrigue or a realistic chronology, but rather defines the apprehension of discontinuous postmodern reality: "Le réel, c'est le discontinu; dès lors, la question se pose s'il est possible de construire le roman, réaliste, du discontinu" (Bertho 96). This discontinuity materialises in the literary field through procedures such as collage, fragmentation and hybridisation. As far as fragmentation is concerned, Gontard names its postmodern practice as fragmental: "une écriture consciente d'elle-même, une esthétique concertée [...] une écriture spontanée, discontinue, qui ne délivre que des vérités provisoires" (2013: 102-103). For its part, postmodern hypertextuality practices quotation, rewriting and metatextuality. In this way, the writing is governed by 'l'état d'incertitude extrême qui double tout acte d'écriture. L'affirmation par le doute, la défiance face à toute forme 
de systématisme [...] À époque incertaine, récits indécidables" (Blanckeman 2000: 11). Thus, the postmodern uncertainty principle brings to the irresolvable stories that Bruno Blanckeman defines as follows:

Pluralité, différences, simultanéités, paradoxes: tels en seraient les paradigmes structurels. Fictions problématiques, par attraction et détraction indivises du romanesque; identités simultanément instituées et destituées, par des écritures autobiographiques inédites; langage à la fois ordonné et subordonné, dans des œuvres qui font de sa domination leur dynamique essentielle (2000: 13).

About les écritures de soi, Viart and Vercier (2005) analyse the postmodern practices of l'autofiction, le journal, le carnet, les récits de filiation and les fictions biographiques. Blackeman refers to them as fictions de soi, and he defines and organises them through three practices that we will find in Navarre's work: autodiction, autoscription and autofabulation (2002: 9-10). Postmodern autofiction is indispensable to understand the transformations of the writing of the self in this period and of the use of the epistolary matter within this literary expression. Autofiction is generated when applying the uncertainty principle to the identity issue (Gontard 2001: 291). Authors as Vincent Colonna (1989), Jacques Lecarme (1993) Marie Darrieussecq (1996), Philippe Forest (2007), Philippe Gasparini (2004, 2008), Philippe Vilain (2010) or Claude Burgelin (2010), among others, have delved into the autofiction concept and its development in literary theory. Thus, while Colonna studies autofiction defined as fictionnalisation de soi, Darrieussecq, for her part, tackles the pragmatic statute of autofiction between fiction and récit factuel, considering it as a practice of the first-person novel. Its double pact -autobiographical ('veuillez croire que') and fictional ('veuillez imaginer que')- defines its nature: "Le texte autofictif est donc un texte indécidable en bloc. 'Fictionnalisation' du factuel et 'factualisation' du fictif'" (378). Taking up Blanckeman's analysis about les récits indécidables, the author explains the mutation of autobiography into autofiction and its relationship with otherness: 
Le récit autobiographique bascule d'une dominante -récit de vie/discours sur soi- à une autre -figuration/défiguration d'une identité subjective, dans des cheminements romanesques ou méditatifs qui mettent à mal l'idée de personnalité constituée. Ces récits posent l'inconnue de soi comme équation, l'apprivoisement de sa propre altérité comme mire [...] connaître l'autre du moi, par le biais du récit autofictionnel; connaître le moi en l'autre, par le biais du récit transpersonnel (2002: 21).

The principle of otherness in relation to contemporary culture is widely studied in the eighties and nineties. Paul Ricœur (1990) organises it in three dimensions: altérité propre or altérité prime, altérité d'autrui and altérité de la conscience. Julia Kristeva defines this otherness from the Freudian concept of l'inquiétante étrangeté (278). Marc Augé, for his part, links it to ethnographic studies and defines it as altérité intime, considering it as a "nécessité au cœur même de l'individualité, interdisant du même coup de dissocier la question de l'identité collective de celle de l'identité individuelle" (1992: 29-30). Zygmunt Bauman tackles it from the concept of strangeness, defined as the existential and mental ambivalence universalised in the postmodern era (1991: 101). The experience of alterity finds its limit in death, since it becomes "the 'absolute alterity' of non-being" (2006: 50). The immanence of death and the mourning process in the intimate space is another essential topic of postmodernity. Navarre's work explores its immanence through that death in first degree that reveals the meanings "of eternity, of uniqueness, of individuality in its twin facets of la mêmeté and l'ipseité" (2006: 42).

This fruitful diversity of studies on the experience of otherness converges on the notion of diversel as a postmodern reality: "si la modernité rêve l'universel, la postmodernité qui affirme une réalité discontinue, fragmentée, archipélique, postule un diversel dont la loi essentielle reste celle de l'hétérogène" (Gontard 2013: 41). In Navarre's writing, renarrativisation, discontinuity and hypertextuality generate a dense prolixity and a narrative complexity that also materialise in the epistolary material generated by its characters. In the author's work, both diaristic and epistolary writing are elements of maximum significance in relation to the characters that produce them, while generating multiple literary constructions 
from their hybridisation (Lannegrand 2012). With regard to the letter, we find the epistolary activity on a recurring basis until it becomes a central element of the narrative in several of his works, since it allows to develop "le motif central du Même et de l'Autre" (Lannegrand 2000: 81).

\section{Characters' Epistolary Writing within the Narrative: Renarrativisation and Discontinuity}

Epistolary correspondence of Navarre's characters appears mainly in two spaces: love and family relationships. Already in his first novel, Lady Black (1971), the author announces the importance that epistolary material will have in his work. First, there are two letters written by its protagonist, Julien, which are destroyed, exposing the following reflection on the epistolary act: "Les lettres ne sont jamais que des mensonges et des comédies pontifiantes. De la bonne discutaillerie d'adolescent" (1971: 32). Next, the importance of the epistolary narration in the protagonist's work is relieved while it is problematised through the critics of both epistolary interlocutors: "Une lettre ne peut vivre que si elle arrive dans une enveloppe [...] Une lettre tue un roman. Ou bien le roman ne doit être fait que de lettres [...] Une lettre dans un roman, c'est un roman qui meurt" (35). In Les Loukoums (1973), Killer (1975) and Ce sont amis que vent emporte (1991), Navarre continues generating the epistolary writing of his characters in their love relationships to confirm both its necessity: "Je porte en moi des angoisses indélébiles que seule l'encre bleu roi peut mater: les angoisses ne supportent pas le miroir de l'écriture" (1973: 65), and its impossibility: "Mais cette lettre, cher Tony, je ne te l'enverrai pas. Elle n'est qu'un exercice de solitude, une manière de me distraire de ce que tu n'es pas encore pour moi. De ce que je voudrais tant que tu sois" (1975: 36).

In the family space we also find the importance of epistolary writing. In Le coeur qui cogne (1974), it gravitates around the deceased son and brother, Jacques, who performed an original ritual with the letters received: "Jacques ne lisait jamais les lettres qu'il recevait. Mais 
il les gardait. Cachetées. Il les mettait dans les poches de son duffle-coat pendant huit jours, quinze jours. Puis un jour, il les classait et les jetait derrière l'armoire ou les glissait sous son matelas" (1980: 110). This epistolary ritual is followed by others, insisting on the crucial symbolic value that is given to the missive: letters saved but never read, blank letters and naked postcards. In this way, the epistolary practice becomes a defining feature of the character, of his worldview and his personal relationships. In Je vis où je m 'attache (1978), epistolary writing is linked to the long marriage of the parents, Gabriel and Adrienne. Gabriel's letter to his sister exposes the wounds and failures of their family life. Adrienne also remembers the letters Gabriel wrote to her during their engagement; missives that caused her disappointment and regarding which she imagined different ones: "Je pourrais, si je le voulais, réciter les lettres imaginaires écrites à Gabriel depuis des années, et les réponses reçues, dictées par moi-même, pondérées, douces, juste les réponses que j'attendais" (1989: 232). In the denouement, Gabriel looks for the letters Adrienne sent to him during the war and offers their content to the reader. Thus, it is evidenced the chasm between the correspondence dreamed up by Adrienne and the real one, so far from the desired love passion and from responding to the recipient's expectations. Once again, epistolary material demonstrates amorous disappointment.

Le Jardin d'acclimatation (1980) generates another family portrait, that of the Prouillan, around the fortieth birthday of the youngest son, Bertrand, twenty years after being subjected to the lobotomy that should have cured his homosexuality. Thus, Navarre materialises a clear example of Philippe Lejeune's concept of autobiographical space (1996). The importance of the epistolary writing in the family and the love spheres converge in this work. The chronicle of this 9th of July in the life of all of them -Henri, the father, and his four children: Sébastien, Claire, Luc and Bertrand- reveals the irremediable breaking of their emotional bonds. The characters' epistolary writing materialises the yearning for communication among them and the despair of its failure. The novel begins with an epistolary self-quotation, belonging to one of 
Bertrand's letters to his brother Sébastien: "Je ne peux aujourd'hui que t'offrir ce jardin dans lequel nous grandirons toujours sans le savoir, sans le vouloir" (1980b: 5). The second chapter presents the letter Sébastien wrote to his father, testimony of the family conflicts, and that, once again, will not be sent. These failed epistolary essays are kept inside a copy of Mémoires d'Hadrien, legacy of his brother Bertrand, where he keeps another letter never read before, the one that Bertrand gave him on his wedding day (34). Chapter 11, epicenter of the novel, presents the 29 letters written by Bertrand, between seventeen and eighteen years old, addressed to Romain, thirty-four. The love relationship, which is broken after being discovered by his father, is then narrated through Bertrand's first epistolary person. On this occasion, the breakup needs the ritual of epistolary destruction: "Jette mes lettres, je t'en prie. Je constate que si on nous sépare, nous nous séparons aussi. Il n'y a que le souvenir de l'encre pour être mémoire inscrite" (223). Afterwards, the narrative shows Bertrand's letter addressed to his aunt and uncle, after Romain's suicide. This time, the epistolary correspondence is the object of another ritual through which the character is able to survive:

Je sais que Romain vous a tout légué, y compris les lettres que je lui ai adressées et qu'il n'a pas jetées. Je sais aussi que vous voulez me les rendre. Je vous demande de les garder et de les lire pour mieux les effacer d'une mémoire amoureuse et sincère (232).

The epistolary material emerges multiple times as a key piece of the family relationships. Claire narrates these letters to her children. Later, Yves reads the letter they had written to her, before their holiday departure. Sébastien rereads Bertrand's notes on the Memoires d'Hadrien copy he gave him on his birthday. Likewise, a note by Anne-Marie when leaving Luc, which he keeps in his wallet, is transcribed. Every letter seems to be accompanied by a survival ritual. In chapter 15, José, at Bertrand's request, reads aloud the last letter Romain wrote before committing suicide, in which he tells the conversation with Bertrand's father and reflects on the existential expectations put in epistolary communication: 
Toute lettre, hélas, est un diagnostic. On attend d'elle, comme de toute poésie, de tout théâtre, de tout roman, de toute musique ou de toute peinture, une explication, pas trop logique, de faits, ou une absurdité hermétique à base d'impressions qui n'ont plus aucune relation au vécu. Or, il n'y a de vécu que ce qui est lancé vers l'autre (308).

The presence of the letter continues with Bernadette's farewell and the one that Claire addresses to her deceased husband. This epistolary writing of grief allows to communicate with the absent, makes it present through writing: "Mon Gérard [...] Tu commences seulement à me manquer [...] tu es l'encre de ce stylo et la page qui reçoit" (355). Later, in chapter 20, Bertrand's letter to Sébastien is also shown. The addressee keeps it inside the book, unread until then. Once again, this epistolary text offers the narration subject and presents the identification between the letter and the novel, the letter as a yearning for literary writing: "Composition française. Sujet: le jardin d'Acclimatation. Forme: libre. Pour: Sébastien. Par: Bertrand. Écrit: comme une lettre, seul véritable roman, un seul auteur, un seul lecteur" (372). After completing the reading, Sébastien returns the letter to the book, where he also keeps the letter to the father, and throws it into the sea (379). Bertrand also destroys Romain's letter, burning it with his photograph (384). The gravity of the epistolary object seems to impose the need for a ritual, either to achieve its destruction or to ensure its conservation.

Louise (1986) is also situated in a family space from the first scriptural person of the protagonist, whose autobiographical narration constantly changes from the first to the third person, between her past life experience and a present that can only be placed at the end of the story, in 1986. Once again, Louise's writing inserts her own diary and past writings, her husband's diary and the notes he leaves her in their daily relationship. In addition, the thirteen letters sent during the war by her son Damien, who died in 1945, which make up chapter 15, are crucial to the story. The relationship between mother and son is shown through them, from Damien's point of view, and the family tragedy is narrated, presenting what Louise is not able to write. After being expelled from the house by his father, Damien settled in Paris from where 
he wrote the first letter to Louise (1986: 113). In the absence of a response from his mother, Damien imagines those non-existent letters: "Tes lettres se perdent toujours. Mais je les lis avec amour" (121). He only received a single letter from her, after announcing his departure to the front, which is commented in one of his letters: "Je partirai avec ta lettre [...] Je la garderai précieusement [...] Avec cette lettre de toi, rude, dure, reçue ce matin. Tu seras contre mon cœur" (123). Louise transcribes Damien's last letter (125) and finally manages to address her deceased son to explain the relationship between the two writings: "J'ai souvent abandonné mes romans parce que j'avais du courrier en souffrance [...] C'est beau, le courrier en souffrance. Beau comme un titre de roman [...] Je réponds enfin au courrier de Damien” (170-171).

In Hotel Styx (1989) the death of the hotel guests is sometimes preceded by their epistolary writing. In two cases, the letters are addressed to people already passed away. Thus, a novelty appears in Navarre's work, since both characters introduce the idea of a future meeting, suggesting, at least, a transcendence hitherto alien to the author's oeuvre. Jonathan addresses Lammert, who was his partner (1989: 32); Julien writes up to six drafts addressed to his mother, also dead by suicide in the sender's youth. The lucid expression of the absolute alterity of death described by Bauman is then produced: "“Tu es l'infinie parenthèse de ma vie," before suggesting the reencounter: "À vite nous revoir, comme on dit, quand on croit qu'on revoit les siens après le grand départ. Je t'aime" $(106,109)$.

Douce France (1990) focuses on the family environment of Geneviève Brabant. Her aunt Ginette, with an amorous past similar to that of her niece, will also write a letter before her suicide, addressed to her assistant, Joseph Bouillard, whom she will tell about her wishes around the actions to be taken after her death, and to whom she indicates: "Un jour, si vous le jugez nécessaire, faites parvenir cette lettre à ma filleule" (1990: 97). He does so and Geneviève reflects on after reading it: "On écrit sur ce que les autres effacent" (99). This sentence is already present in the autobiographical writing of Romans, un roman, as we will see below. The 
epistolary quotation as an intertextual element is another element of Navarre's work. Chapter 18 tells the epistolary activity of Geneviève during the night before her move to the house that Ginette had left her in inheritance. Thirteen missives of which only the first one will be sent to Joseph Bouillard. However, the rest of them, addressed to family members, are all discarded, destroyed. Once again, the epistolary device is the tool to tackle the always avoided family issues. However, the epistolary experience fails (150). She also writes to Ginette, again achieving the presence of the deceased through epistolary writing: "Je sais que tu es debout et que tu lis ce que je t'écris au-dessus de mon épaule. Je sais aussi que si je me retourne tu disparaîtras dans l'instant" (150). This image of the absent recipient reading above the sender's shoulder will be repeated in the next two novels. Finally, Geneviève writes to herself: "Ce n'est même pas la peine que je t'écrive. Les êtres humains ne s'écoutent pas, ne se lisent plus: ils se surveillent”. Epistolary writing is, once again, an exercise of self-objectivation from which the human being does not come out well: "Sous le bureau, la panière est pleine de lettres déchirées. Geneviève a fait le tour d'elle-même. Elle se sent prête à affronter" (152).

In Poudre d'or (1993) the life experience of Roger Poquin (Wanderlust) is marked by the absence of his theatre partner Cécile Sarlat, deceased 17 years before. Once again, the suicidal death of the character is preceded by epistolary writing. The letter becomes a chapter of the novel (1993: 117-122). As an already usual element in Navarre's works, chapter 26 shows six letters from Roger to the absent Cécile. One again, epistolary writing reaches the presence of the disappeared addressee: “j'ai besoin de t'écrire, je le fais, et je sais que tu sais, à lire audessus de mon épaule [...] Je veux me noyer dans cette lettre" (161). Besides, this time the absent addressee manages to stay thanks to her link with the epistolary material: "Vous avez tout lu? Je peux déchirer?" (164). The epistolary writing allows to accomplish the mourning: “je n'écris cette lettre que pour moi [...] Je sais enfin qu'il faut que je te dise adieu et que j'abandonne la mémoire de nous deux" (162). 
In Dernier dimanche avant la fin du siècle (1994), a novel published after the author's death, Navarre's epistolary writing in both spaces, love and family, is synthesised in two letters: Cynthia's letter to her son John, the novel protagonist; John's letter to his ex-partner, Yulen, who is serving a life sentence in an American prison. Regarding the first one, again, it materialises the conflicts of family bonds: John tells about the letter to his friends and makes them speculate about its falsity or truthfulness. In the second, the love bond materialises through epistolary writing: "Je t'attends, cela se fera. Ou si ça ne se peut pas, ça existe dans les draps de ces pages" (1994: 104), and it achieves, once again, the presence of the addressee: "comme si Yulen avait lu la lettre, au fur et à mesure, au-dessus de son épaule” (151). In addition, the first letter is included in the shipment of the second. The intimate family bond is thus shared with the loved one (113). The novel epilogue informs us that the couple's correspondence has not been preserved by either of them, and that the suspended love finally achieved the reencounter thirteen years later, to share Yulen's death.

We realised how epistolary writing is used as a final attempt to make up for failed relationships as well as to managed the absolute absence of the love ones, which inevitably becomes identity reflection: "whenever being speaks of that other, it finds itself speaking, through a negative metaphor, of itself" (Bauman 1992: 2). These letters carry out a constant back-and-forth between life and death, allowing the presence of the absent and offering different mirroring effects about suicide and self-annihilation, which continue along all his oeuvre.

\section{Epistolary Diary and Epistolary Metadiscourse: Hybridisation and Hypertextuality}

For the first time, Le Petit Galopin de nos corps (1977) mixes past epistolary texts and diaristic activity in a mourning experience accomplished thanks to this writing. In this way, Roland's chronicle of the days following Joseph's death (May 12, 1935) alternates with past missives and diaristic texts by both of them, through which their over thirty-year-old relationship is told. 
In addition, epistolary diary materialises: the you emerges in the diaristic text and, therefore, the writing is addressed to a recipient. It could be analysed as the fictional evolution of the journal adressé studied by Françoise Simonet-Tenant (2009).

After the transcription of Joseph's first letter (June 1899), in the first chapter, Roland begins the chronicle of the mourning in the second, Premier jour, from which the enunciation to the recently deceased emerges: “Je n'écris pas, Joseph, je t'écris. On écrit toujours quelqu'un. Je ne recrée, ni ne recrée Joseph, je veux le retour ici..." (1978: 28). This shift from the third to the second person occurs again on the second day (third chapter): "je dis nous, Joseph, quelle joie!” (32-33). Next, the narrative shows the portraits exchanged by the lovers in 1901 (chapters 4 and 5), in which the same shift takes place. The first, Roland's portrait by Joseph, is part of the epistolary enunciation of the latter. The second, however, Joseph's portrait by Roland, is written in the third person, until it reaches its conclusion, when direct addressing seems again inevitable: "Et voici notre vie. Plus qu'un jeu, ne crois-tu pas? Quand tu auras lu ces lignes, j'aurai lu celles que tu es en train d'écrire à mon intention" (55). The diaristic account of the third day (chapter 6) begins already as an epistolary diary offered to Joseph: "Nous étions tout à l'heure réunis, chez toi, à Saint-Pardom, après la cérémonie" (56). At the end of the chapter, the epistolary diaristic writing becomes an encounter space with the absent: "Ils m'appellent cette fois tous en chœur. Je te quitte" (67). The following three chapters include the past diaristic writing of both characters in 1905 and 1906. In the second of them, Joseph's diary entry, the enunciation addressed to the you emerges again, to whom he confesses his writing is dedicated, because of his love desire: "J'écris ceci pour Roland, oui, pour toi, mon ami, afin que tu saches si jamais, ici, tu me lis, que je ne suis pas dupe de toutes tes fiertés" (76). Therefore, the epistolary diary is linked, first, to the present mourning writing and, secondly, to the absence of the loved one during the relationship: 
Chaque ligne, ici, est œuvre absolue. Je suis à la fois l'auteur, l'éditeur, l'imprimeur et je n'ai besoin que d'un lecteur. Chaque ligne: exemplaire unique, pour toi Roland, dédicacé.

Et ce texte, tu ne le liras que plus tard, peut-être jamais, puisque je le dissimulerai (80).

The following chapter, a chronicle of the seventh day of absence, begins with the epistolary addressing: "Me voilà, Joseph, le cœur en creux, à nous recopier" (98), in order to achieve the presence of the absent: "Te dire, Joseph, que j'ai eu un instant l'impression de t'entendre me parler, le comprendrais-tu?" (102). This encounter space is reaffirmed in the ending: "À demain" (105), and in the diaristic writing of the following day, the eighth, since it becomes totally epistolary, describing itself as the deferred dialogue that defines it: "Comme si elle savait que depuis une semaine je passe mon temps de nuit, et mon temps de jour, le temps des matins, à te parler" (109).

Once this transformation from diary to letter is completed, the novel inserts the past epistolary exchange through six letters (chapters) belonging to 1907 and 1908. The chapters dedicated to days thirteenth to sixteenth are all developed within this space of the epistolary diary: "Tu es là"; “Tu vois Joseph, tout s'inachève. Rien ne s'oublie. Tout s'oblitère et continue"; "J'ai rêvé, Joseph!"; “Ce texte, pour nous livrer ne nous délivrera pas" $(145,155$, 156, 166). Next, Joseph's past writing (1912 text) arises again from this diaristic-epistolary space: "Mais au plus profond de toi et de moi, Roland, tout est saccagé, mouvant, émouvant aussi" (172). Separated by the double marriage with the sisters, Sabine and Clothilde, Joseph then transcribes the letters exchanged after their wedding night and continues with two more missives written by Joseph the following year, in which both will be parents (186). The twentyfirst day of mourning, the epistolary diary turns into a figuration of the love relationship: "Ce cahier sera notre œuvre", "Ce cahier est comme la paume de ta main, je l'embrasse pour te dire merci. Tant de jouissance encore!"' (196-197). In the conclusion of this mourning epistolary diary (twenty-seventh and twenty-eighth day), Roland finally says goodbye to Joseph before moving to Paris: "Ceux-là, un jour, peut-être, liront ce cahier comme un bel aujourd'hui. Adieu, 
Joseph, je referme ce cahier comme un plumier!"' (221). Three sentences end the novel, without being able to identify its author: "Un cahier dans un tiroir fermé à clef. L'aventure comme le texte est effraction. Je vous en supplie" (223). Writing and existence are thus linked, as is the case in most of Navarre's characters. The epistolary diary is generated as communication with the absent one that also draws on his writing.

In Kurwenal ou la Part des êtres (1977), published the same year, the fragmentary writing of its protagonist, Pierre Kurwenal, shows a first experience of that shift from diaristic to epistolary writing, which would occur naturally, and about which the character interrogates himself: "Suis-je en train de vous écrire une lettre? Il ne me restera plus qu'à garder ces petits bouts de papiers, ces feuilles, noter de nouveau" (1977: 149). In this case, the diaristic writing becomes epistolary facing first the idea of the farewell: "Un jour, Sarah, tu me liras. Et toi aussi David. Vous deux. Sensualité: on aime toujours l'amour des autres. Personne à qui dire adieu" (157); and of its materialisation afterwards (334).

Le Temps voulu (1979) presents a large epistolary writing of its protagonist, both to his lover and to his other relationships. Pierre Forgue, about to turn forty, writes his first novel, autobiographical, about his relationship with Duck, Daniel Carbon, twenty-two years old. The narrative then develops itself as a metatext of that literary writing and, since its inception, and at different times, it is addressed to the you, Duck, identifying literary and epistolary writing $(1981: 8,23,45,49-50,52,64,67,99,110,155-162,181,237)$. This relationship is clearly established in the second page of the text:

Et si je parle, en te tutoyant, comme si tu étais là, à m'écouter, c'est parce que dans le secret des pages, le silence des signes, et au détour des phrases, je souhaite que tu aimes comme j'ai aimé, que tu vives comme j'ai vécu et que tu t'interroges comme je m'interroge encore [...] Voici mon premier roman (8).

The literary work is a message to the absent: “Ça, Duck, tu ne l'as jamais su. Et c'est ça que tu as rencontré. Je te le livre aujourd'hui, au risque de justifier tes silences" (45). Epistolarity 
is also linked to metadiscourse, to the development of the writing we are reading: "Et c'est tout ça que tu as eu dans tes bras, Duck. À toi. Chapitre 7" (52). When the narrative comes to the account of the separation, the literary text is addressed to the absent person, becoming an unattainable alterity, always imagined, never real: "Et je te retrouve ici, Duck. Et je te garde. Et je me questionne. Et c'est tellement toi, qu'il s'agit d'un autre que j'ai aimé. Figuré. Pas toi” (110). The writing addressed to the you allows, once again, to grieve and reflect on the life experience. Chapter 21 is completely dedicated to this writing to the you-which disappears almost completely in the rest of the novel-, materialising the reflection that gives it its title (155). The you, first vehicle of the literary metadiscourse, then turns into the narrative voice to describe the three days they were together before Duck's journey. In addition, Pierre's correspondence becomes literary material that not only he transcribes but he also reflects on. The correspondence with his fellow professor, Jean-Claude Roussel, interned in a psychiatric hospital, and that with his friend Marie accompany the main missives between the lovers. Pierre's epistolary act towards Duck often results in failed attempts: "J'ai peur du courrier. Je me défends d'attendre une lettre, mais je l'attends [...] Plusieurs fois, je commence une lettre [...] puis je déchire [...] Je déchire encore" (114). Chapter 17 begins with one of Duck's letters to Pierre that the latter reads and rereads, becoming a love fetish of compulsive reading: "Mais on la garde. On y tient. On est toujours le chercheur d'or de quelqu'un. Les mots miroitent ou pèsent lourd au creux de la main. On tient la lettre, on la relit" (133). Chapter 23 consists of the transcript of three letters received by Pierre and written on the same day, July 11, by Duck, Charles and Marie. His reading prompts again, to reflect on the epistolary purpose: "Il ne faut pas répondre. Il ne faut pas écrire. On blesse toujours, quand on écrit, surtout quand on veut faire plaisir, aimer, animer un peu” (177). Later, Betsy's letter includes a surprising reflection on the addressee, materialising the idea of the letter as a cruel ambush into which to fall: "Tu es insupportable [...] Tout le monde te rejettera, toujours" (188-189). Pierre then receives a 
postcard from Duck that he immediately throws away. The epistolary object is either ignored or it becomes obsession. A new letter and two postcards from Duck, throughout his trip through Eastern Europe, again prompt the reflection on their rereading and possession: "Cette lettre et ces deux cartes, je les ai lues, relues, pour me détacher de Duck [...] On croit se détacher quand en fait on s'attache" (199). Later, he will copy the letter he sends to Roussel to keep it, thus confirming the epistolary nature as an inner monologue, a self-addressed text: "On s'écrit toujours à soi-même, et à un certain point de bonheur, de heurt, ou de malheur, chacun se sauve comme il le peut. Je recopie" (242). In its outcome, the conclusion of the writing of the novel, Pierre reflects on the bond between literature and epistolary matter: "Je viens de me relire, ici, comme on relit une lettre [...] Nous sommes devenus les autres de quelqu'un. Quelqu'un d'autre qui lirait cette lettre" (251). The idea of literary writing addressed to the you is then retaken, and compared with epistolary writing, since it would symbolise the impossibility of alterity in the love experience; the you becomes a third person offered to an unknown being. The $I$ does not reach the you but goes astray as a he/she observed from the outside; a new metaphor for the search of an alterity always unattainable.

With Romances sans paroles (1982), the author begins a kaleidoscopic literary practice in which the different stories about each of its numerous characters finally make up an overall image whose central motive is the suicide of a minister, Jean Hanssen. Thus, six letters written by different characters are also instrumentalised in the construction of this narrative puzzle. Among them, Jean's letter addressed to Sam, found in a pocket of his sender's lifeless body after his suicide. His family and friends will discover in his diary several texts also addressed to him, thus presenting the form of the epistolary diary again: “C'est son journal! Des pages comme des lettres"” (1982: 179). Once again, we find in it a reflection on the link between epistolary and literary writing, in turn metaphor of the love relationship: 
La lettre, c'est le roman à l'état naissant quand personne ni rien encore ne lui dicte d'être autre chose qu'un message pour l'autre, une autre, un autre. La lettre, c'est le tout début d'un couple qui ne sera jamais annoncé comme tel, hors du secret d'une lecture, et désigné ainsi par d'autres. Celles et ceux-là qui veulent enfermer une rencontre dans une définition. Non (180).

The practice of this kaleidoscopic literature deepens its complexity in his next work, Premières pages (1983), a novel conceived as the first 41 chapters of an equal number of novels and/or as the 41 possible first chapters of a single work, in which its protagonist and author, Peggy Carnieri, generates the narrative by hybridising the third-person fiction with the firstperson diaristic enunciation. In the former, we find three chapters composed of three letters $(6$, 14, 23), and many others in which missive fragments are transcribed. The diaristic autobiographical space, shown in nine chapters $(4,7,9,12,15,19,24,38$ and 41$)$, is extended in 28, composed of the letter Lola writes to Peggy. Once again, diaristic writing makes the shift to the epistolary diary. While Lola is generally enunciated in the third person in the first six fragments and there are only some references to her through the you, after the beginning of the love relationship the last two fragments are addressed to her: "ma Lola" (1983: 246).

\section{Autofictional Space}

With Biographie (1981) Navarre enters the territory of autofiction to create a controversial work of this literary practice: between autobiography (Lejeune 1986: 44-45), autobiography in the third person (Lejeune 1980), autobiographical novel and autofiction (Gasparini 2004, Lecarme 2004). The narrative is generated from the diaristic writing to hybridise the enunciation in the first and third person, as stated on its back cover: "Commencé le 15 mars 1980, achevé le 24 septembre, jour de ses 40 ans, BIOGRAPHIE est, de front, le roman de tous ses romans précédents, et le journal du texte en train de s'écrire" (1981). In this way, the author is the subject and object of his literary creation, in which he narrates himself in the first and third person alternately, providing a first experience of his own otherness: "The project of Biographie 
is seen as a remedy for that splitting of the self $[\ldots]$ between 'being what he is' and what 'others want him to be"' (Marshall 629). This hybridisation, as I will analyse below, will be developed in several later works: "comme si l'auteur optait pour un genre hybride ou se mêlent écriture autobiographique et écriture romanesque" (Lannegrand 2005: 100). Thus, Navarre includes his own correspondence in this autofictional writing. The letters, usually exchanged with friends and family, mark the whole work. Besides, for the first time it includes the epistolary correspondence with his readers, of great significance to the author, and on which he also reflects: "Seules les lettres de lecteurs anonymes, hommes et pour la plupart femmes de mon âge, pas voyeurs, ceux-là qui ont recours au roman comme un au secours, me permettent d'aller, élan. Et je me réfugie ici” (Navarre 1991: 74). In addition, Navarre shares the writing process with his friends and they give him their opinions and encourage his work. Jean-Jacques and especially Marie-Claude are the closest interlocutors about his literary work. Navarre writes to them on May 31: “je vais vous lire cette lettre [...] Le texte, quand il est, n'est que lettre destinée à un lecteur unique ou appelée à être lue à voix haute: ainsi naquit le roman par le poème et la voix" (244).

Chapter 57, entitled Les Lettres, shows three letters. The first one is written by Yves in 1959 and addressed to his father the summer before proposing him the lobotomy. A real letter in which the importance of epistolary material in Navarre's family experience is undoubtedly revealed, and also transferred to his literature, in this case to Le Jardin d'acclimatation. He expresses extreme sincerity about parental responsibility: “Tu détruis tout le monde autour de toi", "Tu rends tout dramatique", "Je commence à croire que tu détestes tout le monde -ou plutôt que tu ne sais aimer personne, pas même toi" $(424,425)$. The importance of the letter is such that the priority is fixed in the need to be preserved also by the sender: "P.S. Peux-tu garder cette lettre. Je n'ai pas ici ma machine. Cette lettre est trop importante pour que tu sois seul à l'avoir" (427). We then verify how this need to preserve the epistolary object, as part of the 
emotional reality of the interlocutors, responds to the author's reality, which also transfers to his literary work, as well as the absolute need for epistolary communication: "Deux heures et quart du matin [...] J'attends des lettres. Je ne sais pas de qui, mais j'attends des lettres. Tout à l'heure, je serai devant la porte quand le facteur passera" (507). Chapter 75 takes up the epistolary title, Une lettre de Marie-Claude, to show his friend's perception of his writing (575). Both the family letters -especially those addressed to his father- and the love letters -to his lovers enumerated as Rupture $n^{\circ} \ldots$ - show the autobiographical nature of the literary missives.

Another letter to the father, in 1972, precedes the addressee's heart attack, and Yves' brother tries to untie both events: "Surtout, ne te sens coupable de rien [...] Il n'y a aucun rapport entre la lettre et cet accident. Compris?" (589-590). Again, the autobiographical account reveals the relevance of the epistolary matter in Navarre's life experience, as well as a new letter to the father, written twenty years later. It causes the father's phone call after its reading and a second letter after his rereading: "Pourquoi persistes-tu à écarter de toi tous ceux qui t'approchent? [...] Et voilà̀ que vingt et un ans plus tard je t'écris la même lettre" (596). In this way, the failure of epistolary communication and also the urgent need to persist is revealed, showing a possible cause of its compulsive practice. Epistolary writing stands as a tool for managing emotional ties, which explains the need for its insertion in the literary space. The epistolary text, therefore, becomes hypertext that circulates through Navarre's works. In chapter 82 the author transcribes the letter with which Le Petit Galopin de nos corps begins, a novel that is then revealed as inspired by the figure of Navarre's grandfather and his relationship with his brother-in-law.

Chapter 91 focuses again on the epistolary issue, describing and reflecting on the correspondence with his readers, repeating the above-mentioned sentence of Le Petit Galopin de nos corps: "La lettre est le premier et plus parfait de tous les romans: l'auteur est à la fois éditeur, imprimeur, diffuseur, c'est l'œuvre parfaite" (679). At the narrative's conclusion, 
epistolary exchange is again recognised as a kind of interpersonal failure, an always frustrated longing:

Courrier: pourquoi ceux-là de mes amis, proches, me disent-ils souvent 'je t'ai écrit une lettre mais je n'ai pas osé te l'envoyer'? Ils ajoutent parfois: 'je préfère te dire à voix haute ce que je t'ai écrit'. Lettres mortes sur des bureaux amis. Je reçois tant de lettres qui ne me sont jamais envoyées. Et je jette les lettres que je reçois (679).

In Romans, un roman (1988), consisting of seven stories, we find again the epistolary writing of its characters. In the first story, the encounter between father and son, Henri and David, is preceded by an epistolary exchange, a decade after their last meeting. In the third story, Raillac's diaristic narrative becomes an epistolary writing addressed to a "cher n'importe qui" (1988: 246) who is finally identified with the sender himself: "Quand on écrit, on s'écrit [...] En m'écrivant, je voudrais pouvoir apprendre à m'écouter, en me relisant découvrir ce qui s'est cassé en moi, où, quand et comment" (247). This self-correspondence keeps the dédoublement I-you: "il écrit, ce ne sera pas une lettre mais un texte pour lui et lui seul" (248). As on so many occasions, the character destroys the letter to rewrite it. Vercoff's literary writing is also generated through epistolary enunciation: "Chère Rachel" (260), and he insists on the link between both of them: “première page du roman qu'il n'écrira pas, du roman comme une lettre, où finit la lettre, où commence le roman, c'est toujours au secours, pour tout le monde", "Le roman devient lettre" (260-262).

Diaristic writing arises again in the fourth and seventh stories. In Les fleurs de la mimai, Navarre's autobiographical chronicle of his illness includes his correspondence, as was already the case in Biographie: eight letters received and two sent. In Carnet de bord, the author reflects on his work and receives a letter from a reader. In it, the identification between author and reader, always present in Navarre's work, is revealed in all its power: 
Quel est le rôle que je joue, moi, dans ces romans? [...] Sans le savoir probablement, j'attendais. [...] j'attendais mon roman, celui où Yves Navarre s'adresserait à moi, m'interpellerait nommément, me dirait, tout en disant lui-même. Biographie [...] Seraitce excessif de dire que j'ai lu ce livre comme si je l'avais écrit? Non. C'est mon livre, lecteur, autant que le tien, écrivain, puisque tu me l'as offert en partage [...] P.S. Mon adresse. Pourquoi? Parce que ce n'est pas une lettre anonyme. Aussi parce que j'ai appris que toujours, vaguement ou désespérément, on attend une réponse (617-619).

Navarre also reveals that David's letter to his father, belonging to the first story, is the one he wrote to his. The novel concludes with the author's confession, which will reappear in Douce France, about the meaning of this work, revealing perhaps another purpose of the epistolary writing: “quand la douleur, cousine de la mort, est là, les autres n'ont pas et plus de place. Pourquoi? On écrit sur ce que les autres effacent" (693). Epistolary writing would thus serve to write what others erase, in an endless rewriting process that only confirms the impossibility of achieving otherness, in any of its materialisations.

\section{Auto/alter-fiction and Récit Indécidable: le diversel postmoderne}

L'Espérance de beaux voyages (1984) is the first and only Navarre's novel properly epistolary, that is, exclusively composed of letters. However, the work constitutes a sort of epistolary hieroglyph that overflows the canonical definition of what is called epistolary novel, since its dense prolixity and discontinuity destroys any possibility of generating a narrative, as this genre would postulate:

Il apparaît clairement que seule la construction romanesque crée le roman épistolaire. Un ensemble de lettres ne peut être lu comme un roman que si l'organisation de ces textes autorise cette lecture. Il faut que l'ensemble du texte se construise par les lettres, et que celles-ci soient le support de la narration et le moteur de l'action [...] Il faut aussi que les lettres forment une suite permettant à l'action de se développer ou de se construire, soit en donnant naissance à une confidence épistolaire, soit en libérant une action dont les lettres seront le moteur et le support (Calas 42-43). 
Quite the contrary, the text is a limit-experience of epistolary literature that pushes the complexity of its intellection to the maximum through its discontinuity, fragmentation and saturation: 'CC'est un univers de monades arbitrairement rapprochées par une volonté chaotique et imprévisible, c'est un monde de dissemblance et d'isolement qui est figuré par la désorganisation" (Joye 128). The work consists of two volumes divided into the four seasons; 366 missives for each day of the year. A daily epistolary writing that begins on June 24, 1983 with the first volume Eté-Automne (EA), and will conclude in the second, Hiver-Printemps $(H P)$, on June 23, 1984. Thus, this epistolary collection does not belong to a limited and assumable number of senders and recipients or does not build a narrative through its ordering either. Addressers and addressees of all ages and conditions -called by their names, family or love nicknames, initials, etc., or that remain anonymous- generate epistolary texts of unlimited contents too, as the review of the back cover of the first volume advances: "Ce roman, composé de lettres écrites chaque jour, au fil des saisons, pressent et sollicite le lecteur comme collecteur et auteur de correspondances". With such an approach, the reader will be encouraged, based on different characteristics of the text, to seek unity and meaning in the narrative, to solve this sort of epistolary hieroglyph. Analysing the sending network of the 366 letters, we observe that there is no epistolary exchange between the identified interlocutors, that is, none of the letters in which the sender and the recipient are identified receives a response. In addition, only two senders (Bruno and Yves/Y) write more than one letter to the same addressee. However, an inquisitive reading may discover some correspondences in the unidentified letters. On the other hand, many of the names of the senders and recipients will appear in the texts of other letters, causing a resonance effect that again prompts the reader to search for the possible coincidences among the letters interlocutors and the narratives they contain. The epistolary work, therefore, is gradually defining itself as one of the maximum expressions of the postmodern récit indécidable, which, in this case, is generated through the saturation of the epistolary structure 
achieved through the postmodern elements analysed above: dense renarrativisation of the epistolary content, discontinuity -fragmental writing and hybridisation with different textual forms- and hypertextuality -quotation, intertext, and more particularly metadiscourse.

As the author himself indicates on the back cover, the work thus tackles the concept of postmodern otherness, the experience of being other, which also includes the reader by turning him into a "collecteur et auteur de correspondances". Navarre transfers the postmodern diversel of dissemination and heterogeneity to the epistolary novel, in order to transform the narrative by letters into successive and irresolvable experiences of otherness, to both the literary author who creates them and the reader who receives them. In the conclusion of the text, a definition about the meeting of epistolary activity and literature is offered, considering the epistolary genre as "rencontre de l'esthétique et de l'existentiel" (HP: 266), as well as a peculiar interpretation of the novel: "n'importe quelles lettres, même de rédacteurs tous différents, donneraient une sorte d'écho du monde, fût-ce sans autre lien que de se succéder" (HP: 267). An accurate definition of this epistolary experience of postmodern literature.

Within this indecipherable epistolary net, fifteen letters belong to Y./Yves, which identify with Navarre. In this way, autofiction breaks into the fictional space of the narrative with the inclusion of the missives attributable to the author, in a use of his correspondence that already took place in Biographie and that now hybridises with fiction. Seven of them focus on the metadiscourse of literary creation. In his third letter, Yves deepens his metadiscursive reflection on the work in progress:

Le projet qui me tenait était hors programme, hors jeu, et, comme il m'est arrivé de l'écrire dans une précédente lettre, hors je. Comme si d'autres que moi pouvaient écrire les lettres que je suis le seul, et seul, à écrire. Comme si. Comme si un autre que l'auteur pouvait être l'auteur (EA: 156).

Navarre thus describes what could be called the experience of scriptural otherness, which would allow to abandon the ipseity in order to perceive his writing in each letter as an 
alien one, belonging to the countless senders. Autofiction -fictionalisation of the self- is thus transformed into an alter-fiction -fabulation of being other- through a fragmental epistolary writing of uncertainty that becomes a testimony to the postmodern conception of identity: “Aujourd'hui il ne s'agit plus que de lettres et que de l'être, l'être chacune, l'être chacun. Des lettres que je souhaite, en fait pour l'autre, celle ou celui, destinataire, qui lira, recevra, ou bien prendra comme s'il avait lui-même ou elle-même écrit" (EA: 156). It is, therefore, an epistolary literary writing of postmodern chaos that is only perceived as unitary through the concept of the ephemeral, the apprehension of the furtive moment. Yves' letter would define here the essence of a properly postmodern epistolary literature, and the creation of a new auto/alterfiction:

Comme si l'auteur à ne parler apparemment que des autres ne parlait jamais de lui-même. Et vice versa. Le seul fait d'écrire est un outrage. Ici, même, je n'ai pas le droit de me présenter. De faire acte de présence. Comme si. Comme si un autre que moi pouvait être lui ou elle. L'autre. Peut-être. Je continue (EA: 157).

His fourth letter concludes with a sentence that expresses the need for this writing, whose objective would oppose the definition of the canonical epistolary novel in order to establish the goal of this roman épistolaire indécidable: “Quand les lettres n'ont plus de sens alors le sens commence" (EA: 218). Once the impossibility of generating a unitary epistolary narrative through its reading is accepted, a new experience emerges from this epistolary labyrinth: the experience of otherness. In his ninth letter, again anonymous, we recognise Yves for its content. The recipient identifies with the otherness in its broadest sense: "Mon moi. Mon toi. Mon émoi. Ma tribu. Mon brut. Mon inconnu. Mon singulier. Ma différence. Mon fatal. Ma passante. Mon inconnu. Toi, mon couple" (HP: 24). He presents the indécidabilité of the work in progress to this otherness: "Je ne peux pas expliquer toutes les lignes, de toutes les lettres, de tout ce que j'ai écrit pour toi, pour te redonner le sourire et la parole. Je ne peux même pas t'expliquer pourquoi tout cela est inexplicable" (HP: 24-25). The work thus conceived is 
configured as an impossible mission. A literary activity with no purpose and no identifiable addressee: "Cette lettre du milieu de la nuit était à toi, pour toi, sans nom, sans prénom. Qui estu? Ce projet est de ne jamais nous rencontrer" (HP: 27). In this way, we verify how Yves's epistolary writing is generated, for the most part, in relation to the metadiscursive reflection on the work itself and to the disquisitions about the nature of epistolary writing. In his sixth letter, Navarre generates a lucid reflection on the correspondence with his readers: their missives are also an act of literary creation. The letter concludes with a postscript that could be considered as synthetic definition of auto/alter-fiction: “Typographiquement le mot 'autre', l'autre, est une coquille du mot 'auteur', l'auteur. En fait c'est le même mot. L'auteur se doit autre" (EA: 243). The letter also becomes a metaphor of the bond between the reader and the author: "La maladie de celle ou celui qui attend une lettre [...] Le lecteur voudrait le [l'auteur] quitter, mais il envoie toujours la lettre qu'il faut, ou bien la lettre arrive toujours au moment opportun, pour que tout recommence de plus belle" (HP: 243).

La terrasse des audiences au moment de l'adieu (1990) generates a new Navarre's diaristic enunciation between April 21 and August 20, 1989, in which he describes his decision to leave Paris and his move to Montreal, where he lived for two years. Once again, various letters are transcribed, totally or partially, showing the eclecticism of their epistolary relations: friends, lovers and different professional contacts. On this occasion, however, letters are dedicated to farewells before their departure, and the literary and epistolary metadiscourse is not developed, except for two letters to Emanuel, in which the failure inherent to the epistolary activity is reiterated: "J'inaugure cette lettre avec le sentiment que je vais tout te dire, sachant qu'à la dernière ligne l'essentiel ne sera toujours pas dit. C'est la loi des correspondances quand elles ne transigent pas" (1990: 129-130). Besides, he continues developing the auto/alter-fiction space through his identification with Sébastien K.: "Quelle différence y a-t-il entre Yves N. et Sébastien K.?" (92), while they coexist in different chapters: "Yves N. appelle Sébastien K. au 
secours, un texte d'avant, en avant. Qui perd, perd" (198). This auto/alter-fictional character also keeps correspondence with Navarre himself (chapter 26) and with a reader, Nadja (chapter 45). He receives an anonymous letter that includes a very extensive transcribed poem (chapter 66): a poetic version of the hybridisation between auto/alter-fiction and epistolary writing, since we discover the biography of Yves Navarre in its lines. The first three verses become the poem refrain; a poetic synthesis of the author's auto/alter-fiction:

\author{
Il était une fois je \\ Je suis nombreux \\ Je suis toi. \\ Qui m'a écrit un jour \\ Se sachant condamné (325).
}

The récit indécidable focuses on this self/alter-fiction and the identification between the two implies continuous and inapprehensible shifts: "Petite annonce du jour, Navarre cherche Yves désespérément. Ou plutôt, formule. Navarre cherche Yves inespérémenl. K. revient à l'assaut [...] C'est Yves qui écrit, pas Navarre. Sébastien K., voyageur clandestin, vient de hausser les épaules" (322-323). Even one of Navarre's texts included in L'Espérance de beaux voyages is retitled now: "Le bureau des enfants perdus, ou Contes et Légendes de Sébaslien $K . "(258)$ and then the intertext changes its author. In this way, the resounding expression of self-alterity/otherness appears, gathering all the approaches mentioned in the introduction: "Il voudrait tant ne pas avoir à rentrer pour revenir, il, lui, Yves. Ce n'est plus Navarre qui écrit, c'est l'autre, l'autre qui est en lui” (191). In the denouement, Sébastien Klein dies metaphorically in Navarre's arms (377). The penultimate chapter, entitled Mort de Sébastien K. describes the death announced above (384) and shows his farewell text: "va, la vie va, mon frère, et surtout si tu corriges ce texte, ne le mutile pas, nous avons subi trop de punitions" (387). The final chapter consists of various dedications, including one addressed to the epistolary senders, offering a new definition of the impossibility of epistolary realisation: "Je dédie ce texte à celles 
et à ceux qui ont un jour lancé une bouteille à la mer, avec un poème en guise d'appel, leur nom et leur adresse, qui n'ont pas la réponse souhaitée et qui l'attendent encore" (387).

The epistolary matter is also present in Navarre's journalistic experience. In his weekly collaboration with the Montréal newspaper Le Devoir -from September 1990 to September 1991, entitled Carnets-, a year later compiled in the volume La Vie dans l'âme (1992), Navarre also includes the epistolary matter in this new writing task: letters from the readers (Carnets 16, 43); those received from his friends (Carnets 22, 28, 31, 37, 40, 43, 46, 50); or an open letter addressed to Richard Desjardins (Carnet 33). In Carnet 37, Navarre transcribes a letter from his friend Jean-François in which the sender expresses the awareness of the fact that his letters have become the subject matter of the addressee: "Depuis que tu publies certains de mes propos, je n'ose plus citer de noms" (1992: 187). A new mise en abyme of the epistolary writing is thus generated.

The author also brings together his different writing alterities, generating new experiences of auto/alter-fiction. He becomes Sevy Erravan on Carnet 13, "moi, Sevy Erravan" and finally asks himself: "Qui, qui est Sevy Erravan?" (70, 71). In Carnet 43, the author transcribes a letter from a reader who addresses him with that name. That is to say, not only does the author identify himself as an other, but the reader retakes that writing alterity:

Cher Sevy Erravan, quel soulagement, le samedi 15, de retrouver votre Carnet, le numéro 39. Après la prose ignoble d'un certain "oublions-son-nom" qui, sous prétexte de faire une critique de votre livre, s'est laissé aller à décharger des tonnes de fiel, de mesquinerie, de jalousie (215)

Navarre becomes Misaël on Carnet 27, which begins with a letter from him to Elsa, his father's cousin. However, epistolary writing is abruptly interrupted, and Navarre retakes the enunciation to identify the text as belonging to a never-published novel, La Rivière enchantée, and identifies himself with its character-narrator: "Et Misaël, moi, reprend son Carnet, s'y tient, s'y contient $[\ldots]$ Le Carnet alors semble dire 'ça m'appartient'. Et le roman s'arrête là où le 
Carnet commence" (137). Misaël is also the protagonist of a new novel, Petites choses de la vie sans importance, whose otherness Navarre designates as: "mon substitut [...] Une soumission à la mascarade littéraire?" (138), and finally identifies both their childhoods: “L'enfant Misaël, ou l'enfant Yves, devrait accorder sa lyre. Mais le brouhaha l'emporte. Et nous nous laissons faire?" (139). Carnet 49 begins with a fragment of the mentioned novel, this time narrated in the third person, to be interrupted by Navarre asking himself: "Fiction? Réalité?” (248), problematising that frontier of creation again. Carnet 51 retakes Misaël's epistolary writing to Elsa from Carnet 27 to repeat it first and continue it later. A new hybridisation arises: the first person epistolary writing of La Rivière enchantée becomes a story inserted in the work Petites choses de la vie sans importance. The epistolary writing generates a literary work that in turn is inserted into another. After the repetition of the question: "Fictions?", Navarre retakes the narrative to reflect one more time on this space of auto/alterfiction: "Ici. Je, il, elle, Misaël, moi, lui, l'autre, tout se confond, ce ne sera jamais assez d'amour, ce sera toujours trop d'isolement" (259).

Sébastien K. and Henri Martin appear fleetingly in two stories included in Carnet 44. Martin is credited with a quotation "Ce qui est imprimé est factice" (223) that appears in the last letter to Yoshi in Ce sont amis qui vent emporte, but there credited to Abel Klein. The latter -protagonist of La Ville atlantique (1996)- appears as a character in the narratives of Carnet 41 and 48. In Carnet 45, Navarre brings them all together as writing alterities: "iQui donc a pris ma place et a écrit le texte qui suit? Un autre Abel Klein que celui du Carnet $41[\ldots]$ un certain Sébastien K, un dénommé Sevy Erravan ou le secret écrivain Henri Martin dont on parlera un jour, très fort? (224)". As it happened in L'Espérance de beaux voyages, this auto/alter-fiction is the consequence of la folie d'écrire, of the impossibility of stopping writing: "Fin, toujours la suite, jamais la fin. Un condamné á écrire ne s'échappe pas” (228). 


\section{Conclusions}

Navarre's work offers the perfect exemplification of how epistolary enunciation can be instrumentalised in favor of postmodern literature practices, enabling the renarrativisation, discontinuity and hypertextuality that define it, and generating a stimulating evolution. First, the epistolary writing of fictional characters becomes an element of renarrativisation and discontinuity, allowing a progressive fragmental writing about the failures of amourous and family relationships. Next, its hybridisation with diaristic writing materialises the need to achieve the presence of the absent and its instrumentalisation in literary metadiscourse reveals the bond between epistolary writing and literary creation. Later, these same practices are transferred to the autofiction space, where the possibilities of hypertextuality are further deepened through quotation, intertext and metadiscourse. Finally, the two spaces converge in an auto/alter-fiction in which postmodern diversel materialises through experimentation with otherness. This auto/alter-fiction is first conveyed through an epistolary novel that becomes irresolvable and afterwards through a diary and carnets that generate writing alterities equally irresolvable.

Throughout his entire oeuvre, and in all the mentioned spaces, the abundant metadiscourse about the letter allows to draw a sort of postmodern phenomenology of the epistolary activity. In the first place, epistolary writing is claimed as a feasible and positive selfreflection space, whenever the letter is not intended to be read by the addressee. In this sense, the letters addressed to deceased recipients demonstrate that need for internal dialogue as well as the necessity of achieving their presence and mourning their absence. Therefore, and secondly, it is its reception and reading by the addressee that leads to failure, thus confirming the enormous difficulty of intimate communication with the other: it describes the family breakdown and certifies the impossibility of love relationships. The letter is corrupted by being delivered to the other, becoming a vehicle of lies, concealment, imposture; materialising its 
failure again and again. Facing this experience, epistolary interlocutors generate different reactions: destroying the letter, not reading it, returning it to its sender or on the contrary reading it compulsively. This deep conflict turns these reactions into survival rituals around the epistolary object: keeping them without reading them, sending empty letters, writing the answer to an unread letter, keeping a copy of the sent letter, etc. And nevertheless, in spite of the suffering associated with this epistolary activity, the greatest fear consists of the absence of correspondence, which makes its waiting a psychological torture. On the other hand, correspondence exalts the virtues of friendship and it is particularly beneficial in a specific case: the one established with the readers. Their letters are a place of refuge and understanding for the author. Navarre considers them part of the literary work, since it materialises a crucial premise for him: the identification between missive and literary work. The letter would be the starting point and goal of literary writing, the perfect novel addressed to a single reader. This identity demonstrates the importance of epistolary writing in his conception of literary creation, always in search of otherness: family, love, friendship and also writing through auto/alterfiction. However, the letter confirms, again and again, its failure, the impossibility of maintaining a deep bond with the other: "Entre moi et l'Autre, le contact ne peut s'établir. Autrui demeure celui dont je tente désespérément de m'approcher mais qui reste toujours aussi lointain" (Lannegrand 2000: 104).

\section{References}

Augé, Marc. Non-lieux. Introduction à une anthropologie de la surmodernité. Éditions du Seuil, 1992. Baudrillard, Jean. À l'ombre des majorités silencieuses ou la fin du social. Éditions Dénoël, 1983. Bauman, Zygmunt. Modernity and Ambivalence. Polity Press / Blackwell Publishers, 1991.

— Mortality, Immortality and Other Life Strategies. Polity Press / Blackwell Publishers, 1992

— Liquid Fear. Polity Press, 2006

Bertho, Sophie. "Temps, récit et posmodernité." Littérature, no, 92. Le montage littéraire, 1993, pp. 9097. 
Berrong, Richard M. "A Literary Form for Love: Yves Navarre's My Friends are Gone with the Wind." Studies in 20th \& 21st Century Literature, vol. 28, no. 2, 2004, pp. 352-378.

Blanckeman, Bruno. Les récits indécidables. Jean Echenoz, Hervé Guibert, Pascal Quignard. Presses Universitaires du Septentrion, 2000.

— Les fictions singulières. Étude sur le roman français contemporain. Prétexte Éditeur, 2002.

Burgelin, Claude. "Pour l'autofiction." Autofiction(s) Colloque de Cerisy, edited by Claude Burgelin et al. Lyon, Presses Universitaires de Lyon, 2010, pp. 5-21.

Calas, Frédéric. Le roman épistolaire, Nathan, 1996.

Colonna, Vincent. L'autofiction, essai sur la fictionalisation de soi en littérature. 1989. École des Hautes Études en Sciences Sociales (EHESS), PhD dissertation.

Darrieussecq Marie. “L'autofiction, un genre pas sérieux.” Poétique, no. 107, 1996. pp. 369- 380.

Forest, Philippe. "La vie est un roman." Genèse et autofiction, edited by Jean-Louis Jeannelle and Catherine Viollet. Academia-Bruylant, 2007, pp. 211- 219.

Gasparini, Philippe. Est-il je? Roman autobiographique et autofiction. Éditions du Seuil, 2004.

— Autofiction. Une aventure du langage. Éditions du Seuil, 2008.

Gontard, Marc. "Le postmodernisme en France: définitions, critères périodisation." Le temps des Lettres, Quelles périodisations pour l'histoire de la littérature française du XXe siècle ?, edited by Francine Dugast-Portes and Michèle Touret. Presses Universitaires de Rennes 2001, pp. 283-294.

https://books.openedition.org/pur/33315

— Écrire la crise. L'esthétique postmoderne. Presses Universitaires de Rennes, 2013.

Joye, Jean-Claude. Littérature immédiate. Cinq études sur Jeanne Bourin, Julien Green, Patrick Modiano, Yves Navarre, Françoise Sagan. Peter Lang, 1990.

Kibéda Varga, Áron. “Le récit postmoderne.” Littérature, no. 77. Situation de la fiction, 1990, pp. 3-22. Kristeva, Julia. Étrangers à nous-mêmes. Librairie Artheme Fayard, 1988.

Lannegrand, Sylvie. Personne et personnage. Le malaise identitaire chez Yves Navarre. Peter Lang, 2000.

— "S'écrire, se créer: recherche formelle et quête identitaire chez Yves Navarre." Soi-disant: LifeWriting in French, edited by Julinana de Nooy et al. Newark, University of Delaware Press, 2005, pp. 97-107.

_ “Écriture de soi, fragmentation et hybridité générique: le cas d'Yves Navarre." Les Nouvelles Écritures du Moi dans les Littératures française et francophone, edited by Sylvie Camet and Nourredine Sabri. L'Harmattan, 2012, pp. 45-52.

Lecarme, Jacques. “Autofiction: un mauvais genre?” Autofictions \& Cie, edited by Serge Doubrovsky, Jacqques Lecarme et Philippe Lejeune. Paris: Université Paris X, 1993, pp. 227-249.

_ “ 'Origines et évolution de la notion d'autofiction." Le roman français au tournant du XXI siècle, edited by Bruno Blanckeman, Aline Mura-Brunel and Marc Dambre. Paris, Presses Sorbonne Nouvelle, 2004, pp. 13-22. 
Lejeune, Philippe. Je est un autre. Paris, Éditions du Seuil, 1980.

— Moi aussi. Paris, Éditions du Seuil, 1986.

_L Le Pacte autobiographique. Paris, Éditions du Seuil, 1996.

Marshall, Bill. "The Autobiographies of Daniel Guérin and Yves Navarre.” The Modern Language Review, vol, 90, no. 3, 1995, pp. 622-631.

Navarre Yves. 1971. Lady Black. Flammarion, 1971.

_Les Loukoums. París, Flammarion, 1973

— Killer. Flammarion, 1975.

__ Kurwenal ou la Part des êtres. Robert Lafont, 1977.

— Le Petit Galopin de nos corps. Le Livre de Poche, 1978 [first publ. in 1977, Robert Laffont].

_L Le cour qui cogne. Le Livre de Poche, 1980 [first publ. in 1974, Flammarion].

—Le Jardin d'acclimatation. Flammarion, 1980.

_Biographie. Flammarion, 1981.

_L Le Temps voulu. Le Livre de Poche, 1981. [first publ. in 1979, Flammarion].

— Romances sans paroles. Flammarion, 1982.

_ Premières pages. Flammarion, 1983.

— L'Espérance de beaux voyages. Été/Automne. Flammarion, 1984.

— L'Espérance de beaux voyages. Hiver/Printemps. Flammarion, 1984.

_ Romans, un roman. Albin Michel, 1988.

— Hôtel Styx. Albin Michel, 1989.

_ Je vis où je m'attache. Le Livre de Poche, 1989 [first publ. in 1978, Robert Laffont].

— Douce France. Leméac, 1990.

_L La terrasse des audiences au moment de l'adieu. Leméac, 1990.

_L La Vie dans l'âme. VLB Éditeur, 1992.

_ Ce sont amis que vent emporte. Le Livre de Poche, 1993 [first publ. in 1991, Flammarion].

- Poudre d'or. Flammarion, 1993.

— Dernier dimanche avant la fin du siècle. Flammarion, 1994.

Simonet-Tenant, Françoise. Journal personnel et correspondance (1785-1939) ou les affinités électives. Louvain-la-Neuve, Academia-Bruylant, 2009.

Ricœur, Paul. Soi-même comme un autre. Éditions du Seuil, 1990.

Viart, Dominique, and Bruno Vercier. La littérature française au présent. Éditions Bordas, 2005.

Vilain, Philippe. "Démon de la définition." Autofiction(s) Colloque de Cerisy, edited by Claude Burgelin et al. Presses Universitaires de Lyon, 2010, pp. 461-482. 